\title{
Effect of Weather Parameters on Seed Production of Cauliflower (Brassica oleracea var botrytis L.)
}

\author{
Priyanka Sharma ${ }^{1 *}$, Mohinder Singh ${ }^{2}$, S.K. Bhardwaj ${ }^{1}$ and R.K. Bhardwaj ${ }^{3}$
}

${ }^{1}$ Department of Environment Science, Dr. Y.S. Parmar, University of Horticulture and Forestry, Nauni, Solan, Himachal Pradesh, India ${ }^{2}$ Department of Entomology, Dr. Y.S. Parmar, University of Horticulture and Forestry, Nauni, Solan, Himachal Pradesh, India ${ }^{3}$ Department of Vegetable Science, Dr. Y.S. Parmar, University of Horticulture and Forestry, Nauni, Solan, Himachal Pradesh, India *Corresponding author: priyankaplp80@gmail.com (ORCID ID: 0000-0002-2893-2198)

Paper No. 850

Received: 24-03-2020

Revised: 27-07-2020

Accepted: 22-08-2020

\begin{abstract}
The study on the effect of weather parameters on cauliflower seed production was conducted at three locations viz; Nauni, Saproon and Kandaghat during rabi season of 2014-2015 and 2015-2016 in Solan district of Himachal Pradesh. The location Nauni was warmest, followed by Kandaghat and Saproon. Significant variations in seed yield and yield contributing characters of cauliflower were observed due to execution of different weather conditions. The minimum number of days to initiation of seed stalk, flower initiation, 50 per cent flowering, and seed set in cauliflower (Brassica oleracea var botrytis L.) were observed at Nauni, followed by Kandaghat and Saproon. Number of pods per plant and number of seeds per pod were found highest at Saproon (1055.2pods/plant; 18.4seeds/pod) which is coolest location as compared to other two. The maximum seed yield $(239.6 \mathrm{~kg} / \mathrm{ha})$ was obtained from this location. Nauni and Kandaghat showed reduced seed yield compared to that obtained from Saproon. The lowest seed yield $(174.0 \mathrm{~kg} / \mathrm{ha}$ ) was recorded at Nauni. The forenoon humidity during October to December exhibited significant and positive correlation with seed yield. During January to March minimum temperature showed significant and positive correlation with seed yield during April to June.

\section{Highlights}

(0) The cauliflower growth and development and seed production was mainly influenced by the climatic variables viz, maximum temperature and humidity at three study locations.
\end{abstract}

Keywords: Cauliflower, locations, growth, development, seed, yield

Cauliflower (Brassica oleracea var. botrytis L.) is a biannual and herbaceous vegetable crop belonging to the family Brassicaceae. Cauliflower thrives best in a cool moist climate and it does not withstand very low temperature or too much heat (Din et al. 2007). The temperature in the country remains higher up to mid October after which gradually comes down in mid-December and extends up to mid-February, temperature increases sharply thereafter. Optimum weather parameters are important for crop growth and development. In some cases higher temperature during curd initiation adversely affect yield per unit area hampering vegetative and reproductive growth of plant specially head size and delay in seed maturity. Baloch (1994) recommended that optimum temperature promotes earliness and larger heads. Seeds of cauliflower are produced in the country in a small scale but the maximum amount of seeds of cauliflower is imported from other countries. Cauliflower requires optimum temperature and humidity conditions for seed production. The optimum temperature for cauliflower withstands

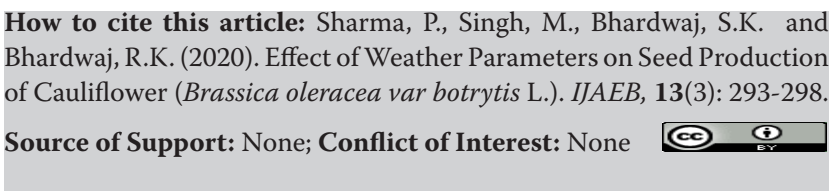
Bhardwaj, R.K. (2020). Effect of Weather Parameters on Seed Production of Cauliflower (Brassica oleracea var botrytis L.). IJAEB, 13(3): 293-298. Source of Support: None; Conflict of Interest: None (C) 
is 10 to $15{ }^{\circ} \mathrm{C}$ (Din et al. 2007). Lavanya et al. (2014) recommended that optimum temperature is suitable treatment combination for higher seed yield. Gill and Singh (1973) studied the effect of environmental factors on seed production of late Cauliflower in Kullu valley between 1958 and 1965 and noticed a great variation in the quantity of seed produced (0 to $291.25 \mathrm{~kg} / \mathrm{ha})$. High mean maximum $\left(16.43^{\circ} \mathrm{C}\right.$ to $\left.18.93^{\circ} \mathrm{C}\right)$ and minimum temperatures $\left(4.67^{\circ} \mathrm{C}\right.$ to $6.83^{\circ} \mathrm{C}$ ) during October, November and December induced good vegetative growth. Fluctuation in temperature in February when curds are formed did great damage and reduced the seed yield by 49.17 to 100 per cent. So, climatically suitable location is needed for quality seed production of cauliflower. Keeping in view, the present study was conducted to find out the suitable location and optimum weather parameters for seed production of cauliflower.

\section{MATERIALS AND METHODS}

The field studies were conducted during 201415 and 2015-16 (October-June) at three locations experimental field Department of Environmental Science, Nauni experimental field located at $31.27^{\circ}$ $\mathrm{N}$ latitude and $76.91^{\circ} \mathrm{E}$ longitude with an altitude of 1300 m.a.s.l, at Saproon $30.91^{\circ} \mathrm{N}$ latitude and $77.09^{\circ}$ E longitude with an altitude of above 1502 m.a.s.l, where the field of cauliflower (Brassica oleracea var botrytis. L) was grown for seed production and Kandaghat research station at $30.51^{\circ} \mathrm{N}$ latitude and $77.12^{\circ} \mathrm{E}$ longitude with altitude of 1425 m.a.s.l in Solan district of Himachal Pradesh. Seeds of variety Pusa Snowball K-1 were sown in the raised beds of $1 \times 1 \mathrm{~m}$ size prepared by mixing FYM in the soil. The seeds sown in the rows and the beds were covered with a layer of dried grass and watered with the help of rose can. Regular watering was done to these beds to maintain proper moisture for the growth of the seedlings. After germination of the seedlings, the dry grass was removed to expose the seedlings to sunlight for better growth. Nursery per bed were kept free from weeds. Timely plant protection measures were also undertaken. Thirty days old seedlings were transplanted in the evening time in the three locations. Healthy seedlings of uniform size were selected for planting. Before transplantation, the nursery beds were irrigated so that the seedlings could be easily uprooted from the beds without any damage of the root. After one week of transplantation, dead seedlings were replaced by planting fresh seedlings to obtain a uniform stand. After transplantation, the three experimental plots were irrigated by watering canes and second irrigation (flood irrigation) was done 3 days after transplantation. Three weeding were done for weed control at 20, 40 and 60 DAT. In the early stage of transplantation damping off disease was occurred in early sowing but serious in late sowing and it was controlled by spraying Bavistin @ $2 \mathrm{~g}$ liter-1 water. Ten plants were selected randomly for data collection. The collected data were analyzed statistically.

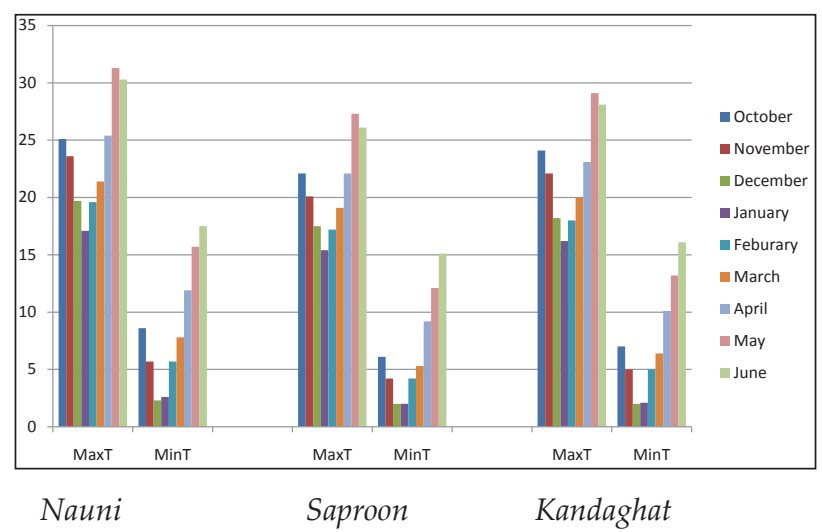

Fig. 1: Mean monthly maximum and minimum temperature of three study locations during the 2014-15

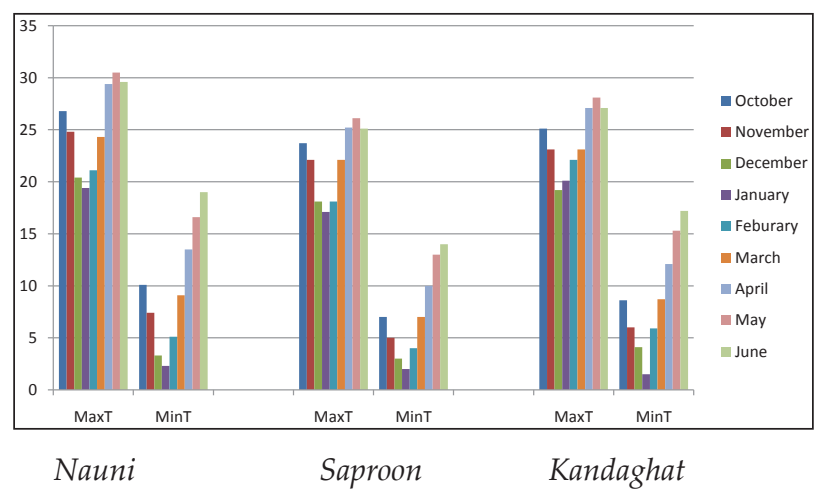

Fig. 2: Mean monthly maximum and minimum temperature of three study locations during the 2015-16

\section{RESULTS AND DISCUSSION}

Effect of weather parameters on reproductive characters of cauliflower in Solan District of Himachal Pradesh.

The data presented in (Table 1 ) revealed no significant difference in number of days to flower initiation between the years. The mean maximum 
Table 1: Effect of locations with variable weather conditions on reproductive characters of cauliflower (Brassica oleracea var. botrytis) in Solan District of Himachal Pradesh

\begin{tabular}{|c|c|c|c|c|c|c|c|c|c|c|c|c|}
\hline \multirow{2}{*}{ Locations } & \multicolumn{3}{|c|}{$\begin{array}{l}\text { Days to initiation of } \\
\text { seed stalk }\end{array}$} & \multicolumn{3}{|c|}{$\begin{array}{l}\text { Days to flower } \\
\text { initiation }\end{array}$} & \multicolumn{3}{|c|}{$\begin{array}{l}\text { Days to } 50 \% \\
\text { flowering }\end{array}$} & \multicolumn{3}{|c|}{ Days to seed set } \\
\hline & 2014-15 & 2015-16 & Mean & 2014-15 & 2015-16 & Mean & 2014-15 & 2015-16 & Mean & 2014-15 & 2015-16 & Mean \\
\hline Nauni & 132.0 & 130.1 & 131.0 & 141.6 & 139.3 & 140.4 & 152.3 & 149.0 & 150.6 & 167.3 & 160.0 & 163.6 \\
\hline Saproon & 136.1 & 133.2 & 134.0 & 145.2 & 142.2 & 143.7 & 154.4 & 151.4 & 152.9 & 171.2 & 165.1 & 168.1 \\
\hline Kandaghat & 134.0 & 131.4 & 132.3 & 142.3 & 140.2 & 141.2 & 152.7 & 150.2 & 151.2 & 169.7 & 163.2 & 166.4 \\
\hline \multirow[t]{2}{*}{ Mean } & 134.0 & 133.5 & & 143.0 & 140.5 & & 153.1 & 150.2 & & 169.4 & 162.7 & \\
\hline & ation & & 0.42 & & & 0.29 & & & 0.18 & & & 0.52 \\
\hline \multirow{2}{*}{$\mathrm{CD}_{(\mathrm{P}=0.05)}$} & & & 0.21 & & & 0.11 & & & NS & & & 0.51 \\
\hline & ation $\times$ ye & & 0.51 & & & 0.61 & & & 0.35 & & & 0.75 \\
\hline
\end{tabular}

number of days to flower initiation was recorded at Saproon (134.0 days) followed by Kandaghat (132.3 days) and minimum number of days to flower initiation was recorded at Nauni (131.05 days). In interaction between year and location maximum number of days to flower initiation was recorded at Saproon (136.1 days) during 2014-15 and minimum number of days to flowering was recorded at Nauni (130.1 days) during 2015-16.

\section{Days to initiation of seed stalk}

The data recorded on different parameters related to seed production of cauliflower at different locations have been presented in Table 1. It is evident from the data that significantly maximum number of days to initiation of seed stalk was observed at Saproon (134.0 days) and minimum at Nauni with 131.0 number of days. The number of days for seed stalk initiation in Kandaghat was statistically at par with that of Nauni. Interaction between year and location was found to be significant; maximum number of days were recorded at Saproon (136.1 days) during 2014-15 and minimum at Nauni (130.1 days) during 2015-16.

\section{Days to flower initiation}

The data presented in Table 1 revealed that mean maximum number of days to flower initiation was recorded at Saproon (143.7 days) followed by Kandaghat (141.2 days) and minimum number of days to flower initiation was recorded at Nauni (140.40 days). Maximum number of days were recorded during 2014-15 and minimum number of days were recorded during 2015-16. In interaction between year and location maximum number of days to flower initiation was recorded at Saproon (145.2 days) during 2014-15 and minimum number of days to flowering were recorded at Nauni (139.3 days) during 2015-16.

\section{Days to 50 per cent flowering}

Similarly, the mean highest number of days to 50 per cent flowering were recorded in Saproon (152.9 days), followed by Kandaghat (151.2 days) and lowest were observed at Nauni (150.6 days). Interaction between year and location was found to be non significant. Between the years, higher number of days to 50 per cent flowering was recorded in 2014-15 than 2015-16.

\section{Days to seed set}

All the locations differed significantly in number of days taken for seed set with greatest number of days for seed set at Saproon (168.1 days), followed by Kandaghat (166.4 days) and lowest were recorded at Nauni (163.6 days). Higher number of days were observed for seed set in cauliflower during the year 2014-15 than 2015-16. Interaction between years and locations revealed highest number of days to seed set in Saproon (171.2 days) during 2014-15 and lowest at Nauni (160.0days) during 2015-16. Among different locations, Saproon was found to be the coolest one. The cauliflower being a thermosensitive crop, due to lower temperature at Saproon, it took highest number of days for vegetative growth and seed set produced optimum sized pods with maximum number of seeds as compared to other locations. At Saproon, cauliflower took the optimum 
growing period and produced the pods of optimum size with higher number of seeds. Similar finding coincide with Patil et al. (1995), Castillo et al. (1992), Bhat (2009) and (Kanwar, 1996).

\section{Yield and yield contributing characters}

Number of pods per plant is an important yield contributing factor for cauliflower seed production, which is significantly influenced by the prevailing growing conditions of a crop. In present studies, significantly. Maximum number of pods per plant (1055.2) was recorded at Saproon, followed by Kandaghat (935.2), were recorded at Nauni (922.2). No significant differences in number of pods per plant were recorded between Kandaghat and Nauni. In interaction between location and year maximum pods per plant were recorded at Saproon 1057.4 during 2015-16 and minimum were recorded at Nauni (915) pods per plant during 2015-16.

At Saproon, cauliflower plants took the optimum growing period which resulted in optimum sized pods as well as in maximum number of seeds pods. Patil et al. (1995) reported that plants grown in early winter when temperature was low produced large sized pods and increased number of seeds per pod because of proper growth and development of the cauliflower plants. The maximum mean number of seeds was also recorded at Saproon (18.4) followed by Kandaghat (15.3) and minimum number of seeds per pods was recorded at Nauni (13.45). Interaction between location and year showed non significant effect on number of seeds per pod. The 1000 seed weight was also recorded highest $(2.87 \mathrm{~g})$ at Saproon followed by Kandaghat (2.35 g) and Nauni (1.67g). The highest seed yield $(239.6 \mathrm{~kg} / \mathrm{ha})$ was also obtained from Saproon which was also statistically at par with Kandaghat $(236.7 \mathrm{~kg} / \mathrm{ha})$. Similar results were observed by Gill and Singh (1973. Sharma and Arora (1984), Wheeler et al. (1995), Azizur Rehman and Nawab Ali (2000), Chatterjee et al. (1990), Hussain et al. (2015) and Gurusamy (1999).

\section{Number of seeds per pod}

The maximum mean number of seeds per pod were also recorded at Saproon (18.4), followed by Kandaghat (15.3) and minimum number of seeds per pod were recorded at Nauni (13.45). Interaction between location and year showed non significant effect on number of seeds per pod. However, in 2014-15 higher number of seeds per pod were recorded than the year 2015-16.

\section{0 seed weight}

The 1000 seed weight was also recorded highest $(2.87 \mathrm{~g})$ at Saproon, followed by Kandaghat (2.04g) and Nauni (1.67g). No significant difference in 1000 seed weight between years was recorded. Similarly, interaction between locations and year was found to be non significant.

\section{Seed yield (kg/ha)}

The highest seed yield $(239.6 \mathrm{~kg} / \mathrm{ha})$ of cauliflower was obtained from Saproon which was also statistically at par with that of Kandaghat (236.7 $\mathrm{kg} / \mathrm{ha}$ ). The lowest seed yield was obtained from Nauni (174.0 kg/ha). In year 2014-15, cauliflower crop produced higher seed yield as compared to 2015-16. Interaction of year and locations revealed maximum seed yield.

Correlation studies revealed that maximum, minimum temperatures and forenoon humidity showed significant effect on seed yield of cauliflower (Table 3). The forenoon humidity $(\mathrm{r}=0.788)$ during October to December exhibited significant and positive correlation with seed yield/ha). During January to March, minimum temperature ( $r=0.808$ ) showed significant and positive correlation with seed yield, whereas maximum temperature $(\mathrm{r}=0.887)$ during April to June showed significant and positive impact on seed yield. In the present studies, higher forenoon humidity during OctoberDecember (vegetative phase), minimum temperature during January-March (curd development stage) and maximum temperature during April-June (Reproduction phase) were found to be critical for cauliflower seed production. Similar observations were also recorded by Gill and Singh (1973), Wheeler et al. (1995), Azizur Rehman and Nawab Ali (2000) and Chatterjee et al. (1990).

In (Table 3), correlation studies revealed that forenoon humidity during October to December exhibited significant and positive correlation with seed yield. During January to March minimum temperature showed significant and positive correlation with seed yield during April to June. 
Table 2: Effect of locations with variable weather condition on seed characters of cauliflower (Brassica oleracea botrytis L.) in Solan District of Himachal Pradesh

\begin{tabular}{|c|c|c|c|c|c|c|c|c|c|c|c|c|c|}
\hline \multirow{2}{*}{\multicolumn{2}{|c|}{ Locations }} & \multicolumn{3}{|c|}{$\begin{array}{c}\text { Number of pods per } \\
\text { plant }\end{array}$} & \multicolumn{3}{|c|}{$\begin{array}{c}\text { Number of seeds per } \\
\text { pod }\end{array}$} & \multicolumn{3}{|c|}{$\begin{array}{l}1000 \text { seed weight } \\
\text { (g) }\end{array}$} & \multicolumn{3}{|c|}{$\begin{array}{c}\text { Seed yield } \\
(\mathrm{kg} / \mathrm{ha})\end{array}$} \\
\hline & & 2014-15 & 2015-16 & Mean & 2014-15 & 2015-16 & Mean & 2014-15 & 2015-16 & Mean & 2014-15 & 2015-16 & Mean \\
\hline \multicolumn{2}{|l|}{ Nauni } & 960.5 & 915.0 & 937.5 & 13.9 & 13.0 & 13.45 & 1.70 & 1.60 & 1.67 & 179.0 & 169.1 & 174.0 \\
\hline \multicolumn{2}{|l|}{ Saproon } & 1053.8 & 1057.4 & 1055.2 & 19.4 & 17.5 & 18.40 & 2.42 & 2.90 & 2.87 & 249.1 & 243.9 & 239.6 \\
\hline \multicolumn{2}{|l|}{ Kandaghat } & 924.4 & 947.0 & 935.8 & 16.0 & 14.7 & 15.30 & 2.10 & 1.90 & 2.04 & 238.4 & 235.1 & 236.7 \\
\hline \multicolumn{2}{|l|}{ Mean } & 979.5 & 973.2 & & 16.4 & 15.0 & & 2.24 & 2.15 & & 222.1 & 216.0 & \\
\hline \multirow{3}{*}{$\mathrm{CD}_{(\mathrm{P}=0.05)}$} & Location & & & 43.4 & & & 1.04 & & & 0.78 & & & 11.1 \\
\hline & Year & & & NS & & & 0.85 & & & NS & & & 4.2 \\
\hline & Location & $\times$ year & & NS & & & NS & & & NS & & & 12.5 \\
\hline
\end{tabular}

Table 3: Correlation coefficient (r) of seed yield of cauliflower seed and weather parameters at three location in Solan district of Himachal Pradesh

\begin{tabular}{lllll}
\hline \multirow{2}{*}{ Months } & \multicolumn{3}{c}{ Temperature $\left({ }^{\circ} \mathrm{C}\right)$} & Humidity (\%) \\
\cline { 2 - 5 } & Maximum & Minimum & Forenoon & Afternoon \\
\hline Oct-Dec & -0.217 & 0.015 & $0.788^{* *}$ & -0.211 \\
Jan-Mar & 0.145 & $0.808^{* *}$ & -0.109 & 0.135 \\
April-June & $0.887^{* *}$ & 0.144 & -0.231 & -0.222 \\
\hline
\end{tabular}

\section{CONCLUSION}

The growth and development of cauliflower was influenced by maximum temperature negatively, whereas forenoon humidity showed positive effect, resulted in higher growth and development parameters (plant height, number of leaves, curd characters etc.) at Saproon followed by Kandaghat and Nauni location. Seed production of cauliflower was influenced by forenoon humidity (OctoberDecember), minimum temperature (January-March) and maximum temperature (April-June) during the study which resulted in maximum seed yield at Saproon followed by Kandaghat and Nauni location. Due to the longer crop duration with congenial weather parameters the seed quality parameters were observed maximum at location Saproon followed by Kandaghat and minimum at Nauni.

\section{REFERENCES}

Alam M, Farooque AM, Nuruzzaman M and Jamaluddin AFM. 2010. Effect of sowing time on growth and yield of three radish varieties. Bangladesh Research Publication Journal, 3(3): 998-1006.

Anonymous. 2005. The year book of Agricultural Statistics of Bangladesh. Bangladesh Bureau of Statistics, Ministry of Planning, Govt. People's Repubublic Bangladesh.
Azizur Rehman and Nawab Ali. 2000. Effect of plant spacing and sowing time on yield of turnip crop. Sarhad Journal Agriculture, 16(60): 775-779.

Baloch, A.F. 1994. Vegetable Crops Horticulture. National Book Foundation, Islamabad, pp. 489-538.

Castillo, H., Quintanilla, C. and Melillo, C. 1992. Effect of sowing date on curd and seed yield in four cauliflower cultivars. Conf. paper of international Society for Tropical Horticulture, pp. 7-12.

Din, F., Qasim, M., Elahi, N. and Faridullah. 2007. Responce of different sowing dates on the growth and yield of cauliflower. Sarhad Journal Agriculture, 23(2): 289-291.

Gill, H.S. and Singh, J.P. 1973. Effect of environmental factors on seed yield of late cauliflower in Kullu Valley. Indian Journal of Agriculture Sciences, 43(3): 234-236.

Gurusamy, C. 1999. Effect of stage of harvesting on seed yield and quality of cauliflower. Indian Seed Science and Technology, 27(3): 29-936.

Incalcaterra, G., Iapichino, G., Stoffela, P.J., Cantliffej, D.J. and Damato, G. 2000. Sowing time influences cauliflower seed production. Italian Acta Horticulture, 533: 45-52.

Hussein, A.S.D. 2012. Climate change and its impact on the productivity and quality of vegetable crops. Journal of Applied Sciences Research, 10(2): 4359-4383.

Jaiswal, J.P., Subedi, P.P. and Bhattarai, S.P. 1996. Findings of seed production study on cauliflower. Working paper of Agriculture Research Center, Nepal, pp. 14. 
ans

Whitwell, J.D. and Senior, D. 1988. Effect of plant spacing of autum cauliflower on head size, curd, yield and quality for processing. Acta Horticulture, 220(1): 235-244
Patil, J.D., Ranpise, S.A. and Jadhav, S.B. 1995. Effect of spacing and date of seed sowing on yield of different cultivars of cauliflower. Madras Agriculture Journal, 82(2): 613-614. 